\title{
Criminal Liability for a Notary Committing a Criminal Act of Fraud in Parallel in the Land Sector
}

\author{
Hadimastika Karsito Putro ${ }^{1}$, I Made Sepud ${ }^{2}$ and I Made Arjaya ${ }^{3}$ \\ \{karsito@gmail.com¹ , sepud.made@gmail.com² and made.arjaya@gmail.com\} \\ Universitas Warmadewa, Denpasar-Bali, Indonesia
}

\begin{abstract}
The study reports the application of the Material Criminal Law by the Public Prosecutor against perpetrators of fraudulent offenses, especially notaries, with a decision number: $207 / \mathrm{pid} . \mathrm{b} / 2014 / \mathrm{pn}$. This type of study is normative study. The results indicate that to achieve material truth by the Panel of Judges of the State District Court is conducted by carefully examining all the acts, events or circumstances that took place during the trial where the facts were extracted from the evidence in the form of witnesses, statements of the defendant and evidence. Apparently these correspond to one another so that it is believed that the actions of the suspect constituted a criminal act that intentionally helped to commit fraud, so that the act violates the provisions of Article 378 in conjunction with Article 65 paragraph (1) of the Criminal Code and the judge sentences the defendants for 2-year imprisonment.
\end{abstract}

Keywords: Criminal act; fraud, liability; notary; parallel

\section{Introduction}

One of the forms of crime that is still extremely widespread in the community is fraud. Even it has been in great concern of scholars in various countries during last several decades, such as those revealed by $[1,2,3,4,5]$. For individuals, criminal act of fraud is not a difficult act to commit. It can be carried out only with the ability to communicate well so that someone can convince others, either through a series of lies or fictitious languages [6]. At present, there is a large amount of fraudulent crimes occur in the society, and they have even evolved epically with various forms. These include criminal law tackles computer fraud [7]; law enforcement on it in Europe [8]; documentary letter of credit fraud under criminal law[4]; attorneys caught in the web of medicare/medicaid fraud [9] and even its occurrence condition on food [5]. This development indicates the increasing level of complex intellectuality of perpetrators of frauds and they bring about dentrimental impact on fair competition of the world [10].

Criminal act of fraud is a type of crime that always occurs and even tends to increase and develop in society following the progress of the times. In fact, such actions never have a noble characteristic because in essence they eliminate mutual trust between the perpetrators and other people, and ultimately damage the order and harmony of people's lives [11]. Ironically, criminal acts of fraud are not only carried out by ordinary people [12], but every person from all social stratification, starting from the lower classes of society to state officials, even the control holders eradicate fraud at once. For example, at some time in the past a group of residents in Bali were deceived by a notary in transactions in the land sector. 
Notary is an institution that carries out partly of the public function of the state in the sector of civil law. The responsibility of the notary for carrying out public functions of this country is contained in the Act of Notary Position, that is to say, "A notary is a public official who is authorized to issue authentic deeds and has other authorities as referred to in this Act or under other laws. Therefore, a notary as a public official is authorized by the state and appointed by the government to make "an authentic deed, namely a deed made in a form determined by law, made by or in the presence of general employees where the deed is made [13]."

The position carried out by a Notary is a position of trust given by the state and society according to the law and $[14,[15]$. Because the position of a Notary is a trusted position, a Notary must have good behaviour. Considering the role and authority of the Notary is very important for the life traffic of the community, the behaviour and actions of the Notary in carrying out his professional position must be vulnerable to the misuse of all legal objects that could harm the community.

The growing community life has an impact on the increasing need for public services that can provide legal certainty [12], one of which is in the field of Notary services. Public service provided by a Notary is within the scope of service for issuing deeds and other duties charged to a Notary attached to the title as a state public official within the scope of the duties and authorities of the Notary. The deed made by a Notary must be strong evidence if legal disputes occur in court. In other words, the deed of the Notary gives the parties a guarantee of perfect proof.

In Article 16 of Act Number 2 of 2014 concerning Notary Position, it is stated that one of the notary's obligations is to act trustfully, honestly, thoroughly, independently, impartially, and safeguard the interests of the parties concerned in legal actions. Nevertheless, there are many Notaries who are caught in criminal cases, both civil and criminal cases. Some of the criminal acts that are often carried out by Notaries are: (1) Falsification of documents (2) Embezzlement (3) Money Laundering (4) Fraud (5) Provision of false information under oath. Of the various types of criminal acts that often occur, the most often done by a notary is a criminal act of fraud.

One of the cases of fraud that attracts attention to be studied from the point of view of normative law is the one that occurred in Bali carried out by a woman notary. In the case, there were dozens of victims who suffered up to hundreds of millions of rupiah. After committing the criminal act of fraud, the perpetrator fled and became a fugitive for 2 years, until finally in 2014 he was arrested and convicted [16].

In the present study, we revealed the conditions of the application of the Criminal Procedure Law by the Public Prosecutor to the notaries as a form of accountability for the crime of fraud committed, namely in the decision no:207/pid.b/2014/pn.Nga. In addition, we also examine legal considerations by the Judge in bringing down notaries the perpetrators of fraudulent crimes committed in parallel. We utilize the normative legal research approach to achieve the objectives of this study.

This type of research is normative legal research. In this study, we examined the phenomena or cases that exist by looking at each case from the applicable legal aspect, that is we compared legislation products to identify whether there is a vacuum of norms, vagueness of norms or legal conflicts or not. Additionally, we collected various types of legal materials as additional data that support the validity of this study data. Legal materials collected are: Criminal Code; Criminal Procedure Code; Law Number 2 Year 2014 concerning Notary Position; Verdict number:207/pid.b/2014/pn.Nga. Apart from legal material, we also collected scientific resources related to fraudulent crimes and the nature of notary functional positions 
within the country. The sources of knowledge in question were scientific books, journal articles and results of previous studies. Other sources of related data and literature to this study were internet.

In data analysis activities: we descriptively described the conditions or existing legal and non-legal propositions; we interpreted grammatical, historical, systematic, teleological, contextual conditions within the existing legal acts and other interpretations in legal objects; we created juridical construction by making analogies and reversing propositions (acontrario); we conducted an evaluation to look back on whether or not it was appropriate or incorrect, agree or disagree, true or false, legal or invalid a legal phenomenon. This activity is supported by propositions, statements of norm formulation, decisions; we also provide arguments to broaden analysis holistically.

\section{Results and Discussion}

\subsection{Application of material criminal law by public prosecutors against perpetrators of criminal act of fraud with decisions number: 207/PID.B/2014/PN.Nga}

In the application of material criminal law with the decision of the state district court, the convicted person is charged by the public prosecutor. The indictment is one of the tasks that must be issued by the Public Prosecutor, the indictment is read out at the beginning of the session, and then the presiding judge asks the defendant whether he really understands. If the defendant does not understand, the public prosecutor shall provide the necessary explanation at the behest of the presiding judge [17]. Theoretically, in the view of the doctrine, there are 3 types of indictments, namely single form, alternative form, and cumulative form, whereas in judicial practice, in addition to the three types of indictments, there are also two other forms of indictments [17]. In a prevalence, law enforcement in society must be avoided far from the concept of nepotism, so that people feel clearly before their eyes what is their dream as a part of the country elements: equality before the law. In its implementation in the field, no matter whether the indictment that is dealing with a court hearing is a law enforcer or others, in order to create a sense of justice and to create a prosperous atmosphere for the community, the charges must be punished according to the applicable law [18]. Even if possible, outside the court system, the means and methods of giving sanctions can be created by the central and regional governments [19] - in this case including traditional elders as thinkers and creators of community law - because provisions that are covered in a country's national court system are not always capable to solve or to be applied in solving problems in a community whose customary system is a dominant living aspect of their lives.

\subsection{Legal considerations of judges in imposing criminal charges against perpetrators of fraud in decision number: 207/PID.B/2014/PN.Nga}

Fraud is a form of crime that is not that which is never pleasing to the victim, and even social distance is caused by it [20]. Even though its type exclusive to a crime that always causes casualties, fraud is an enemy that never unites people everywhere, including criminality as happened in West African state, particularly in Nigeria in its mismanagement of its oil wealth [21]. As it appears to Indonesia nation, the central for the settlement of such criminal act the court. Panel of judges, after all stages of examination completely accomplished, hold to take deliberation based on provisions of applicable law to reach a decision. 
In Decision Number: 207/PID.B/2014/PN.NGA, the panel of judges considers whether based on existing legal facts, the defendant can be declared to have committed a crime charged to him;

Considering: that to declare a person has committed a criminal act, the act of the person must fulfill all the elements of the criminal act charged to him;

Considering: that the defendant has been indicted by the Public Prosecutor, with charges arranged in an alternative manner, namely:

First: Defendant's acts violate the provisions of Article 378 of the Criminal Code Jo Article 65 paragraph (1) of the Criminal Code;

Or;

Second: The defendant's actions violated the provisions of Article 374 of the Criminal Code Jo Article 65 Paragraph (1) of the Criminal Code;

Considering, that because the Prosecutor's indictment was arranged in an alternative manner, the Panel of Judges is given the freedom to consider which accusation is appropriately applied for the Defendant's actions and after observing the facts obtained at the hearing, the Panel of Judges would consider the First Public Prosecutor's charges namely Article 378 of the Criminal Code 65 paragraph (1) of the Criminal Code containing the following elements:

Elements of anyone;

Elements with the intention to benefit themselves or others against the law;

Elements with deception or a series of lies move other people to give something to him;

The element of several acts which must be seen as an independent act so that they are crimes;

Considering: that furthermore the Panel of Judges will consider all the facts of the law and the circumstances revealed at the hearing are related to the elements of the article charged.

\section{Discussion}

Before dropping the verdict, the judge considers the evidence that will be used in the trial as stated in the provisions of Article 183 of the Criminal Procedure Code, which formulates the following: making him get the belief that a criminal act really happened and that the defendant was guilty of doing so. So, for the Judge's conviction, there must be, at least, two valid evidences. In a negative system, there are two things that are requirements, namely wettelijk and negatief. The wettelijk is meant by legal evidence and which is stipulated by law, while the negatief is that with legal evidence set by the law only, it is not enough for the judge to declare that the evidence has been given, but the judge's conviction is still needed, thus between the evidence and the conviction of the judge there must be a causal relationship.

Based on the results of data analysis, it is discovered that the basis of legal considerations for judges of the State District in imposing criminal decisions on Decision Number:207/PID.B/2014/PN. NGA, are:

1. Proof based on evidence as stipulated in Article 184 of the Criminal Procedure Code

2. There are things that are incriminating and alleviating the defendant

In essence, to recognize exactly whether a suspected person is the real perpetrator of a crime or not is somewhat uneasy. Thus, accurate proofs are always the starting point to give rise to a judge's decision on which kind of sanctions shall be imposed based on what types of crimes committed. It is all acceptable that the basic for taking consideration to determine types 
of sanction to be imposed to a defendant is criminal code and criminal procedure code, as the biggest book of Indonesian law stipulating criminal actions. As it came to pass in the existing committed criminal acts, it was so far not able to guarrantee further perpetration of the same criminal acts avoidance and also it was also not able to result in community's satisfaction. Advances in all aspects of human life have brought about sophisticated way in being free of proof of having committed crimes. Thus, examiners should be be so creative in performing examinations and investigations.

In line with this, Article 184 paragraph (1) of the Criminal Procedure Code formulates that there are 5 (five) valid evidence according to law, namely:

1. Witness testimony;

2. Expert information;

3. Letter;

4. Direction; and

5. Defendant's information

In its nature, human would never be in whole lifetime doing things out of mistakes. Now it standing, legal enforcers shall have the nature of deep and pure awareness toward what to take and what to strongly decline in order to create accurate guidelines for community to behave for the public's welfare. The community, such as those from local context, are in need of legal protection and certainty amid the flow of globalization progress highlighted by bad competitions, where situations of social activities among the community often result in fear [12]. Hence, the community surrender their protection to the government through provided rules of law.

\section{Conclusion}

Based on the description in the previous sections of the two issues examined in this paper, the conclusions that can be put forward are as follows: Firstly, the application of material criminal law by the Public Prosecutor to a notary as a fraud offender in Decision Case 207/PID.B/2014/PN.NGA, is the Judges of the State District Court, have carefully and thoroughly examined all actions, events or circumstances that took place during the trial, where the facts were extracted from evidence in the form of witnesses, statements of the defendant and evidence, it turns out that it is in accordance with each other so that they obtain the belief that the suspect has indeed committed a crime of fraud for several times, and that is violating Article 378 in conjunction with Article 65 paragraph (1) of the Criminal Code. Secondly, the judge's consideration in implementing the provisions of criminal sanctions against fraud offenders carried out in parallel by the notary in the case is appropriate; the indication is that the judge has considered both in terms of juridical, facts of the trial, testimony of witnesses, and available evidence, and thus the judge sentenced the defendant to imprisonment for 2 years and the period of detention that has been reduced by the accused all of the criminal sentences and ordered that the defendant remain in detention.

From what was found through this study, the Public Prosecutor and Judges are advised in examining criminal offenses committed jointly by notaries, high demands and criminal sanctions should be given because notaries as public officials should carry out their duties in accordance with the code of ethics Notary Public. The Notary Council of Supervisors is advised to truly supervise, foster and maintain the notary profession in accordance with their 
code of ethics. At least there is no reluctance to give reprimand and impose sanctions when there is a notary who violates applicable law.

\section{References}

[1] Smith, A, T, H.: Regulating Fraud. White Collar Crime and the Criminal Process. By Michael Levi. [London: Tavistock Press. 1987. xxxvi, 357, (Bibliography) 18 and (Indexes) 11 pp. $£ 35 \cdot 00$ net.]," Camb. Law J. pp. 317-318 (1987)

[2] Spahr, L, L and Alison, L. J.: US savings and loan fraud: Implications for general and criminal culture theories of crime. Crime, Law Soc. Chang. Vol. 41 (1). pp. 95-106 (2004)

[3] Levi, M.: Serious tax fraud and noncompliance. Criminol. Public Policy. Vol. 9 (3). pp. $493-$ $513(2010)$

[4] Zhang, Y.: Documentary letter of credit fraud under criminal law regime in England and China. J. Financ. Crime. Vol. 21 (4). pp. 433-446 (2014)

[5] Lord, N., Elizondo, C, J, F and Spencer, J.: The dynamics of food fraud: The interactions between criminal opportunity and market (dys) functionality in legitimate business. Criminol. Crim. Justice. Vol. 17 (5). pp. 605-623 (2017)

[6] Poole, C, J, M.: An HR Guide to Workplace Fraud and Criminal Behaviour. Michael J. Comer and Timothy E. Stevens. Published by Gower Publishing Ltd, 2004. ISBN 0-566-0855-0. \{pound 85.," Occup. Med. (Chic. Ill). Vol. 56 (3). pp. 218 (2006)

[7] Bainbridge, D.: Criminal law tackles computer fraud and misuse. Comput. Law Secur. Rep. Vol. 23 (3). pp. 276-281 (2007)

[8] Seibert, T.: The European fight against fraud - The community's competence to enact criminal laws and its power to approximate national criminal law by directives. Eur. J. Crime, Crim. Law Crim. Justice, Vol. 16 (1). pp. 89-124 (2008)

[9] Douglas, D.: Attorneys Caught in the Web of Medicare/Medicaid Fraud an Overview of an Attorney'S Ethical Duties and Criminal Liability in the Wake of United States V. Anderson. J. Leg. Med. Vol. 21 (3). pp. 395-428 (2000)

[10] Ravel, M.: 12 Conclusion. pp. 401-404 (2008)

[11] Hauser, L., and Nichols, R.: Regulating Fraud: White-Collar Crime and the Criminal Process. no. pp. 20-26 (2006)

[12] Spasi, D and Radovanovi, I.: Security Needs of Citizens and Community Policing in Serbia is There a Link? (2018)

[13] Subekti, R and Tjitrosudibio, R.: Kitab Undang-Undang Hukum Perdata. 34th ed. Jakarta: Pradnya Paramita. (2005)

[14] Isnaini, H and Wanda, H, D.: Prinsip Kehati-Hatian Pejabat Pembuat Akta Tanah Dalam Peralihan Tanah Yang Belum Bersertifikat. J. Huk. IUS QUIA IUSTUM. Vol. 24 (3). pp. 467-487 (2017)

[15] Smith, L, G.: The Role Of The Notary In Secure Electronic. no. September (2006)

[16] C. C. A. 155 paragraph (2) letter B, "No Title."

[17] "Criminal Code Article 155 paragraph (2) letter b."

[18] State, T.: Legitimation and the limits of the criminal justice system. (1984)

[19] Smit, P., Eijk, A, Van and Decae, R.: Trends in the Reaction on Crime in Criminal Justice Systems in Europe in 1990 - 2007 : A Comparison of Four European Regions. pp. 55-82 (2012)

[20] Pickett, J, T and Roche, S, P.: Questionable, Objectionable or Criminal? Public Opinion on Data Fraud and Selective Reporting in Science. Sci. Eng. Ethics. Vol. 24 (1). pp. 151-171 (2018)

[21] Simon, O, Ben.: Demystifying the advance-fee fraud criminal network. African Secur. Rev. Vol. 18 (4). pp. 5-18 (2009) 